\begin{tabular}{|c|c|}
\hline & Asian Social Work Journal (ASWJ) \\
\hline $\begin{array}{c}\text { ASIAN SOCIAL WORK } \\
\text { JOURAL } \\
\text { (ASW) }\end{array}$ & Volume 3, Issue 3, July 2018 \\
& e-ISSN : 0128-1577 \\
& Journal home page: \\
& www.msocialwork.com \\
\hline
\end{tabular}

\title{
Kaunseling Kelompok Terapi Kognitif dalam Pengurusan Stres dalam kalangan Polis
}

\author{
Wan Anor Wan Sulaiman', Wan Nurfatini Wan Anor ${ }^{1}$, Adi Fahrudin'1, Mohd Dahlan Hj. A. Malek ${ }^{1}$ \\ 1Fakulti Psikologi dan Pendidikan, Unviersiti Malaysia Sabah (UMS)
}

Corrrespondence: Wan Anor Wan Sulaiman (wananor@ums.edu.my)

\begin{abstract}
Abstrak
$\overline{\text { Artikel ini ditulis adalah untuk membincangkan tentang penggunaan kaedah kaunseling kelompok }}$ terapi kognitif dalam pengurusan tekanan dalam kalangan anggota polis di Malaysia. Ia juga membincangkan apakah senario tekanan anggota polis, punca-punca tekanan, kesan tekanan yang dialami oleh anggota polis dalam menjalani kerja dan gaya hidup mereka, dan bagaimana programprogram sedia ada yang telah dilakukan untuk mengurangkan tekanan polis. Hasil tulisan ini boleh memberi idea dan cadangan kepada pihak Polis DiRaja Malaysia (PDRM) untuk melakukan intervensi kaunseling kelompok terapi kognitif sebagai suatu kaedah yang boleh diaplikasikan terhadap anggota polis yang mengalami tekanan yang tinggi khususnya dan yang mengalami tekanan sederhana amnya.
\end{abstract}

Kata kunci: tekanan, polis, kaunseling kelompok, terapi kognitif

\begin{abstract}
This article was written to discuss the use of cognitive therapy group counseling method in stress management among police personnel in Malaysia. It also discusses what police stress scenarios, stress factors, stress effects experienced by policemen in their work and lifestyle, and how existing programs have been done to reduce police stress. The results of this paper can give an idea and suggestion to the Royal Malaysian Police (PDRM) in intervention using cognitive counseling group interventions as a method that can be applied to high-stress police personnel in particular and who experience moderate stress.
\end{abstract}

Key words: pressure, police, counseling group, cognitive therapy

\section{Pengenalan}

Dalam mencapai wawasan 2020, Malaysia menuju negara menuju negara industri memerlukan tenaga pekerja yang berdaya usaha tinggi, cekap dan cergas. Masalah yang cukup besar pengaruhnya terhadap pencapaian tujuan itu adalah tekanan di kalangan pekerja merupakan satu halangan kepada produktiviti kerja yang baik. Permasalahan seperti pusing ganti pekerja, ketidakhadiran dan ketidakpuasan kerja adalah antara masalah yang biasa berlaku dalam organisasi masa kini (Donald, et al. 2005). Kesemua masalah ini mempunyai perkaitan dengan stres di tempat kerja (Landy, 1989). Pekerjaan polis sudah pasti ada kaitan dengan tekanan kerja yang dialami mereka. 
Tekanan dalam dunia pekerjaan bukan sesuatu yang baru diperkatakan. Banyak kajian yang telah dijalankan untuk mengkaji hubungan tekanan dengan profesion sama ada dalam bidang profesional atau separa profesional. Tekanan boleh mendatangkan kesan negatif kepada kesihatan mental individu (Ursin \& Eriksen, 2004). Tekanan dalam kalangan pekerja boleh mengundang pelbagai risiko sama ada kepada diri dan juga organisasi. Golongan penguasa seperti polis merupakan salah satu profesion yang bertujuan menjaga keselamatan dan keamanan negara dan profesion ini sememangnya memberi impak kepada kepada pelbagai tekanan terhadap mereka.

Memandangkan kajian terdahulu menunjukkan bahawa tekanan dalam bidang kepolisan adalah sangat serius dan memerlukan pelbagai strategi bagi mengatasi masalah tekanan ini berterusan di alami oleh polis. Kajian yang dibuat oleh $\mathrm{Wu}$ et al. (2010) juga menunjukkan bahawa polis merupakan suatu pekerjaan yang mempunyai tinggi tekanan, dan dipercayai memberi kesan kepada fizikal dan kesihatan mental polis, dan juga tekanan kerja dalam kalangan polis adalah hasil pendedahan kombinasi antara persekitaran kerja dan faktor personal.

Kajian yang dibuat oleh Che Azimah (2008) mengenai tekanan kerja dalam kalangan anggota polis di Kelantan, Malaysia. Seramai 60 orang anggota polis telah terlibat kajian tersebut. Dapatan kajian menununjukkan bahawa terdapat perbezaan tekanan kerja disebabkan oleh faktor demografik, iaitu umur, taraf akademik, masa bekerja dan status. Morash, Kwak, Hoffman, Lee, Cho \& Moon (2008) membuat kajian terhadap 686 pegawai polis di Korea Selatan mendapati lima faktor iaitu tempat kerja yang menyumbang kepada stres adalah gangguan seksual, gangguan emosi yang dianggap seperti tidak wujud, gangguan bahasa diskriminasi jantina, cemuhan dan gangguan rakan sekerja. Myendeki (2008) telah menjalankan kajian mengenai stres pegawai polis di Afrika Selatan. Hasil kajian mendapati stres pekerjaan menyebabkan seseorang mengalami burnout.

Polis menyediakan beberapa perkhidmatan yang pelbagai yang berpotensi kehilangan nyawa. Walau bagaimanapun, di samping menyediakan perkhidmatan ini polis sering di bawah mikroskop oleh media sosial, kumpulan peguam bela, dan masyarakat (Roberg, Novak, \& Cordner, 2005). Akibatnya, tekanan boleh memuncak pada seseorang yang aktif bekerja di persekitaran pegawai polis. Selain berurusan dengan tekanan yang berkaitan dengan kerja seperti duti berbahaya dan tidak menyenangkan yang berakar umbi dalam tugas rutin harian pegawai polis, mereka juga berhadapan dengan tekanan organisasi seperti penderaan di tempat kerja (Hart, Memakai, \& Headey, 1995).

Dalam persekitaran kerja mereka, anggota polis terdedah kepada mengawal ganas individu dan keadaan (Perrot \& Kelloway, 2006). Persekitaran kerja penguatkuasaan undang-undang ini diwarisi dan dibebani (Ivie \& Garland, 2011). Terdapat faktor-faktor tertentu yang terdapat dalam persekitaran kerja polis termasuk pendedahan negatif untuk menilai kesungguhan yang berkaitan dengan kerja-kerja polis (mis membuat tangkapan ganas atau bertindak balas kepada kejadian berdarah), keakraban untuk menilai keyakinan dan kepercayaan di kalangan pegawai polis rakan-rakan (mis amanah kalangan rakan polis), dan ketidakadilan untuk menilai sikap pegawai polis individu terhadap yang menjadi pegawai polis dalam organisasi polis (Zhao, \& Archbold, 2002). Kajian menunjukkan pegawai polis lelaki menunjukkan bahawa pendedahan negatif kepada kerja-kerja polis dan keakraban mempunyai hubungan statistik yang signifikan pada tahap peramalan tekanan (Dia et al., 2002). Sebaliknya, pegawai polis wanita tidak terjejas dengan isu-isu ini (Dia et al., 2002).

\section{Definisi Stres}

Istilah stres seringkali disamakan dengan tekanan. Dalam membuat definisi tekanan setiap orang menunjukkan perbezaan antara satu sama lain. Tekanan adalah berbeza untuk semua orang. Sepuluh orang bermasalah dalam memdefinisikan tekanan dan kesemuanya akan wujud perbezaan (Richard Blonna, 2005). Tekanan merupakan urusan secara menyeluruh antara individu dan yang mendorong tekanan hasil daripada mobaliti badan akibat tindakbalas tekanan. Kajian ini melihat tekanan bersandarkan teori yang dikemukakan oleh Cooper, Sloan dan Williams (1988). Hans Seyle (1976) telah mendefinisikan 'tekanan' sebagai gerak balas fizikal badan terhadap permintaan sama ada permintaan positif atau negatif. Apabila terdapat permintaan, maka terdapat reaksi daripada badan 
manusia. Raja Maria Diana (2011) pula mengatakan bahawa tekanan juga boleh bermaksud sebagai tindak balas emosi yang tidak spesifik terhadap desakan sama ada yang sebenar atau yang diimaginasikan. Ia merupakan satu fenomena semula jadi yang tidak boleh dielakkan sekiranya seseorang itu membuat kerja-kerja profesional. Tekanan merupakan perkara yang normal dalam kehidupan yang sentiasa dipenuhi dengan rasa tidak selesa. Setiap orang akan mengalami tekanan dalam kehidupan seharian mereka. Tekanan yang berterusan dan keterlaluan boleh mengganggu kesihatan mental mahupun kesihatan fizikal seseorang.

Cooper, et al. (1988) berpendapat tekanan bukan semata-mata disebabkan oleh satu punca malah rangkaian faktor menyebabkan berlakunya tekanan. Namun terdapat kemungkinan bahawa suatu punca tekanan itu memainkan peranan yang lebih dominan daripada punca-punca lain dalam sesuatu situasi pekerjaan. Mereka seterusnya mengemukakan 6 sumber tekanan iaitu faktor intrinsik kerja, peranan pengurusan, hubungan dengan orang lain, kerjaya dan pencapaian, struktur dan iklim organisasi dan halangan kerja atau di rumah.

\section{Stres Kerja dalam kalangan Polis}

Stres atau tekanan kerja merupakan satu manifestasi negatif dalam persekitaran kerja pada masa kini dan menjadi isu utama serta fenomena meningkatnya tahap tekanan dalam kalangan pekerja disebabkan bebanan kerja, isu keselamatan di tempat kerja dan peningkatan taraf hidup (Yozgat et. al., 2013). Dalam konteks organisasi kepolisan, isu yang tidak dapat dielakkan adalah masalah tekanan kerja dalam kalangan Pegawai Polis yang pada masa kini merupakan isu yang kian meruncing dan membimbangkan (Masilamani et. al., 2013). Di Malaysia organisasi yang merupakan badan penguatkuasa utama negara adalah jabatan Polis Diraja Malaysia (PDRM) (Mohamed Sazif, 2011). PDRM juga merupakan satu badan bertanggungjawab mempertahankan keamanan dan ketenteraman awam yang tidak terhad kepada ketenteraman yang berkaitan manusia malah bersangkutan dengan bencana alam yang menjadikan PDRM sebagai agensi yang pertama dikehendaki bertindakbalas sekiranya sesuatu ancaman dari dalam negara berlaku (Salmah, 2009).

Kerjaya kepolisan merupakan suatu bidang kerjaya yang penuh dengan tekanan ( Mohamed Sazif, 2011), cabaran ( Kaur et. al., 2013) serta berisiko tinggi ( Hammad et. al., 2013) organisasi kepolisan dalam konteks kajian ini iaitu PDRM, kini berhadapan dengan permasalahan psikologi yang meruncing di kalangan pegawainya di mana terdapat pelbagai kes-kes pembunuhan, mencederakan orang awam, membunuh diri dan masalah mental di dalam negara yang telah dilaporkan melibatkan Pegawai Polis yang gagal mengawal emosi diri akibat daripada tekanan dalam diri (Sinar Harian, 14 September 2013).

Fakta ini dikukuhkan lagi dengan bukti-bukti kajian yang telah dibuat dalam kalangan Pegawai Polis PDRM adalah berada di tahap tekanan kerja yang tinggi seperti hasil kajian-kajian lepas yang telah dijalankan oleh Masilamani et. al., (2013). Namun, hanya sedikit sahaja kajian yang dijalankan dapat menunjukkan tahap tekanan di kalangan Pegawai Polis di dalam pasukan PDRM berada di tahap sederhana (Iran \& Mohamed Fadzil, 2010; Salmah, 2009). Kajian yang telah dilakukan oleh Jabatan Kesihatan Masyarakat Pusat Perubatan Universiti Kebangsaan Malaysia (PPUKM) mendapati profesion sebagai pegawai polis berada di tangga teratas dalam mengalami tekanan kerja berbanding penjawat awam yang lain di mana peratusan kadar tekanan bagi Pegawai Polis adalah sebanyak 53.7\% berbanding dengan profesion lain iaitu Pegawai Penjara (48.8\%), Anggota Bomba (47.3\%), Guru (45.8\%), Jururawat (42.3\%), Doktor (40.7\%) dan Pembantu Farmasi (35.2\%) (Hasmizal, 2007). Malah menurut Masilamani et. al., (2013) Pegawai Polis di Malaysia berpangkat Inspektor lebih mengalami tekanan kerja yang tinggi berbanding dengan Pegawai Polis lain kerana faktor tanggungjawabnya yang berat dalam sudut penyiasatan kes, tugas khas, jenayah komersil, operasi khas (memerangi keganasan) dan jenayah narkotik.

Walaubagaimanapun kajian berkaitan tekanan kerja dalam kalangan Pegawai Polis khususnya di Malaysia dan di Asia Tenggara amnya masih lagi kurang diberi perhatian (Masilamani et. al., 2013). Menurut Wong (2003), kekurangan kajian di dalam organisasi kepolisan di Asia Tenggara adalah 
kerana terdapat kekangan dari segi faktor politik, perbezaan dari segi amalan dan teori kepolisan, organisasi kepolisan Asia yang lebih bersifat konservatif dan keperluan melindungi maklumat sulit. Manakala kajian-kajian lepas dari luar negara juga mendapati profesion kepolisan merupakan kerjaya yang mempunyai tahap tekanan atau stres kerja yang tinggi (De La Fuente Solana et. al., 2013). Kajian dari negara-negara Barat seiringan dengan hasil kajian tempatan yang mendapati tekanan kerja berlaku apabila keperluan kerja tidak seiring dengan sumber, kebolehan dan kehendak pekerja itu sendiri hingga menyebabkan kesan yang ketara terhadap psikologi dan fisiologi pekerja (Jiang, 2008). Seterusnya akan memberi kesan yang ketara kepada kesejahteraan psikologi seseorang individu itu dari segi tingkah laku, kognitif dan fizikal (Mohd Awang et. al., 2010)

\section{Punca Stres Kerja Polis}

Patterson $(2001 ; 2009)$ menyenaraikan lima kategori punca utama tekanan kerja yang boleh berlaku dalam kalangan Pegawai Polis berdasarkan kajian oleh Finn \& Tomz (1997) yang sering digunakan oleh para pengkaji. Punca pertama berlakunya tekanan kerja di kalangan Pegawai Polis adalah daripada faktor organisasi itu sendiri yang lebih berstruktur birokrasi dan bersifat separa tentera di dalam tugasan penguatkuasaan undang-undang (Patterson, 2009). Lazimya faktor organisasi (seperti pentadbiran, jabatan dan lain-lain) dan operasi adalah merupakan faktor yang sering kali menyumbang kepada tekanan kerja yang tinggi kepada Pegawai Polis (Shane, 2010). Selain itu masalah peralatan logistik seperti kelengkapan yang tidak mencukupi dalam menjalankan tugas, gaji yang rendah, waktu kerja shif, penyeliaan dan latihan yang tidak mencukupi merupakan faktor kepada berlakunya tekanan kerja di kalangan Pegawai Polis (Liberman et. al., 2002).

Penyertaan pegawai yang bertanggungjawab membuat sesuatu keputusan dalam organisasi juga menyumbang kepada faktor yang memberi tekanan kerja berbanding dengan Pegawai Polis yang tidak diamanahkan untuk membuat sesuatu keputusan (Slate et. al., 2007). Punca kedua pula adalah faktor tugas kepolisan itu sendiri yang secara langsung dan kerap berhubungan terhadap masalah masyarakat dalam melaksanakan tanggungjawap melindungi orang lain, tugas berisiko tinggi dan lasak yang melibatkan kekerasan dan mengancam nyawa merupakan faktor kepada punca tekanan di kalangan Pegawai Polis. Selain itu faktor lain yang memberi kesan kepada tekanan seperti beban kerja, kerja tidak teratur, kerja lebih masa di luar waktu pejabat serta perlu bekerja tanpa ketentuan masa iaitu perlu bersedia dipanggil bertugas pada bila-bila masa walaupun waktu bercuti, cuti tidak mencukupi, kurang masa bersama keluarga, tekanan politik, kurang sokongan organisasi, kerap berpindah tempat kerja, imej negatif daripada masyarakat, risiko kepada bahaya dan keganasan juga menyumbang kepada tekanan kerja di kalangan Pegawai polis (Kaur et. al., 2013). Punca ketiga adalah daripada persepsi masyarakat, media dan pengamal undang-undang terhadap sistem kehakiman yang lebih bersifat kemasyarakatan menyebabkan keputusan sistem kehakiman lebih memihak kepada pesalah dan berlaku ketegasan pula dalam proses penguatkuasaan polis melalui beban bukti dan penyiasatan yang terlalu teliti hingga menyebabkan masyarakat dan media memandang negatif terhadap tindakan penguatkuasaan polis. Hal ini menyebabkan tekanan terhadap Pegawai Polis di dalam melaksanakan penguatkuasaan undang-undang (Patterson, 2009). Punca keempat berlakunya tekanan di kalangan Pegawai Polis adalah daripada masalah peribadi seperti masalah keluarga, masalah kewangan, dan sebagainya yang dapat menyumbang kepada peningkatan tekanan terhadap diri seseorang Pegawai Polis (Patterson, 2009). Punca kelima adalah daripada tuntutan tugas Pegawai Polis itu sendiri yang sering berhadapan dengan peristiwa-peristiwa trauma semasa membantu mangsa yang secara tidak langsung menyebabkan risiko gangguan tekanan akut dan gangguan tekanan selepas trauma (Patterson, 2009). Di dalam kajian yang telah dilakukan oleh Anderson et. al., (2002) mendapati Pegawai Polis yang pernah mengalami tekanan tinggi adalah mereka yang sering berhadapan dengan situasi tugas yang traumatik dan mereka akan merasai perasaan trauma walaupun selepas tamat tugas. Menurut Collins \& Long (2003), pegawai penyiasat polis yang terlibat dengan persekitaran kerja dan mangsamangsa yang traumatik boleh mengalami imaginasi trauma, tekanan trauma sederhana, traumatic countertransference, burnout dan melemahkan perasaan belas kasihan. 


\section{Kesan Stres Kerja Polis}

Apabila sesuatu tindakbalas tekanan gagal dikawal dengan berkesan ianya boleh mengakibatkan kemurungan berlaku dalam diri seseorang ( McEwen \& Lasley, 2009). Terdapat bukti kajian lepas yang menunjukkan tekanan kerja dapat memberi kesan kepada kesejahteraan hidup Pegawai Polis dan prestasi organisasi (Bakker \& Heuven, 2006). Anshel (2000), menyenaraikan tiga kesan utama akibat daripada belakunya tekanan di kalangan Pegawai Polis iaitu kesan pertama adalah akibat ancaman yang melampau daripada dari pihak luar akan menyebabkan perubahan yang ketara dari segi psikologi, tindak balas fisiologi dan tingkahlaku (Violanti, et. al., 1998). Menurut Yun et. al., (2013), tekanan kerja dalam kalangan Pegawai Polis boleh memberi kesan negatif kepada hubungan dengan rakan sekerja, ahli keluarga, penceraian dan keganasan rumahtangga.

Menurut Anshel (2000) lagi, kesan yang kedua akibat daripada kegagalan menangani secara berkesan tekanan jangka pendek akan menyebabkan tekanan berlanjutan ke fasa tekanan kronik yang boleh menyebabkan gangguan kepada sistem imunisasi badan dan akhirnya membawa kepada masalah kesihatan. Kajian-kajian lepas telah menunjukkan bahawa kesan daripada tekanan dalam diri boleh mengundang kepada pelbagai masalah negatif yang lain seperti kemurungan, tekanan mental, menjejaskan kualiti tidur dan masalah kesihatan (Burke \& Mikkelsen, 2006). Selain itu, apabila berlakunya peningkatan risiko terhadap tekanan dan kemurungan dalam kalangan Pegawai Polis juga boleh menyebabkan risiko yang tinggi terhadap masalah mental dan fizikal termasuk penyakit kardiovaskular iaitu penyakit jantung, tekanan darah tinggi, hypercholesterolemia, gangguan perut, kebimbangan, kemurungan dan gangguan tekanan posttraumatic (Van Hasselt et. al., 2008).

Kajian oleh Joseph et. al., (2009) pula mendapati berlakunya peningkatan tahap atherosclerosis (iaitu pengerasan pembuluh darah akibat mendapan lemak) yang berpotensi meningkatkan penyakit kardiovaskular di kalangan Pegawai Polis berbanding dengan orang awam. Menurut Stinchcomb (2004), tekanan dalam kalangan Pegawai Polis mempunyai hubungan dengan simtom fisiologikal (sakit kepala, sakit perut, sakit belakang, ulser dan serangan jantung). Hal ini kerana apabila seseorang Pegawai Polis mengalami situasi tertekan mereka sering mengabaikan gaya hidup sihat hingga menyebabkan berlakunya masalah kesihatan (Violanti et. al., 2013). Manakala individu yang mengalami tekanan kerja lazimnya lebih tinggi kuantiti menghisap rokok berbanding dengan mereka yang tidak mengalami tekanan kerja (Mendelsohn, 2012) di mana risiko yang tinggi berlakunya penyakit kardivaskular adalah daripada amalan merokok (Ambrose \& Barua, 2004) terutamanya di kalangan Pegawai Polis (Violanti et. al., 2013). Kesan terakhir akibat daripada tekanan kerja dalam tempoh jangka masa yang panjang akan menyebabkan kesan kepada tahap motivasi dan menjejaskan prestasi kerja (Anshel, 2000). Tekanan kerja yang tinggi akan memberi kesan kepada tahap penurunan kepuasan kerja dan prestasi kerja di kalangan Pegawai Polis (Mohamad Sazif, 2011). Bukti ini menyokong pendapat bahawa tekanan dalam organisasi dapat memberi kesan negatif kepada tahap kepuasan kerja seperti kadar pusing ganti kerja yang tinggi, ketidakhadiran, masalah moral dan mengurangkan produktiviti (Norvell et. al., 1998) burnout (Brown et. al., 1996) dan bersara awal (Becker et. al., 2009).

Tekanan darah tinggi merupakan salah satu penyumbang utama penyakit jantung dan stroke. Tekanan darah tinggi menyumbang kepada kematian hampir 9,4 juta orang/tahun akibat penyakit jantung dan stroke, dan jika digabungkan, kedua penyakit ini merupakan penyebab kematian nomor satu di dunia. Hipertensi juga meningkatkan risiko gagal ginjal, kebutaan, dan beberapa kondisi lain. Hipertensi kerap terjadi bersamaan dengan faktor-faktor risiko lain seperti obesitas, diabetes, dan kolesterol tinggi yang meningkatkan risiko kesehatan (Schlein, 2013).

\section{Intervensi Kaunseling Kelompok Terapi Kognitif dalam Mengurangkan Stres Polis}

Organisasi kepolisan khususnya di peringkat pengurusan kepolisan seharusnya peka dan mengetahui tahap tekanan kerja yang dialami di kalangan Pegawai Polis bagi memastikan langkah-langkah pemulihan atau pun pencegahan dapat dilaksanakan. Collins \& Gibbs (2003) menyarankan pendekatan pengurusan stres oleh pihak pengurusan kepolisan dengan mengubah terlebih dahulu persekitaran kerja 
yang agar suasana kerja tidak tertekan, mengurangkan bebanan kerja dan mengurus persekitaran organisasi berbanding dengan hanya memberi latihan pengurusan stres kepada setiap individu.

Pendekatan latihan pengurusan tekanan di tempat kerja adalah bertujuan untuk mengurangkan kesan negatif terhadap kesihatan mental di kalangan Pegawai Polis dan ianya membantu pegawai meningkatkan kemahiran menangani tekanan dalam diri mereka (Patterson, 2009). Berdasarkan kajian empirikal yang diketengahkan telah membuktikan bahawa isu berkenaan tekanan kerja di dalam organisasi kepolisan tidak seharusnya dipandang remeh oleh semua pihak. Kesan-kesan tekanan kerja bukan sahaja boleh berlaku terhadap psikologi dan fisiologi diri Pegawai Polis itu sendiri malah lebih memburukkan lagi ianya boleh memberi kesan negatif terhadap organisasi kepolisan dari segi imej dan kualiti penyampaian perkhidmatan kepada masyarakat. Hal ini disebabkan daripada kemerosotan kualiti dan prestasi perkhidmatan akibat kegagalan mengawal tahap tekanan kerja yang dialami Pegawai Polis.

Pihak yang berkaitan khususnya pengurusan PDRM seharusnya peka dengan situasi tekanan yang dialami pegawainya dan mencari pendekatan yang berkesan untuk menangani masalah ini bagi memelihara kredibiliti dan integriti organisasi. Pendekatan teknik psikologi yang berkesan dan persekitaran kerja yang kurang tekanan adalah salah satu faktor yang perlu dititik beratkan dalam usaha membendung isu ini daripada terus membelenggu organisasi kepolisan. Antara pendekatan psikologi yang hendak dihuraikan dalam artikel ini ialah kaunseling kelompok terapi kognitif.

Kaunseling kelompok didefiniskan secara konsep adalah satu proses interpersonal dinamik yang memberi tumpuan kepada pemikiran dan tingkah laku sedar. Ia juga turut melibatkan fungsi terapi, realiti, katarsis, saling percaya mempercayai, menyayangi, penerimaan dan sokong menyokong (Gazda et al, 2001). Rudestam (1982) melengkapkan definisi ini dengan memasukkan elemen perasaan di mana setiap ahli kelompok akan mengalami perasaan kepunyaan yang merupakan satu keperluan asas manusia (Maslow 1968). Gladding (2008) menyatakan kaunseling kelompok sebagai bersifat pencegahan, perkembangan dan penyembuhan serta mempunyai kesan rawatan yang efektif. Kaunseling kelompok bukan sahaja mempunyai kuasa, perkembangan dan pencegahan tetapi juga berupaya meningkatkan sokongan berbentuk interpersonal dan penyelesaian masalah secara berkelompok. Kaunseling kelompok merupakan perkhidmatan menolong yang dilakukan secara berkelompok dengan tujuan untuk membantu individu yang mempunyai masalah yang sama, berinteraksi, menjaling perhubungan secara psikologi, pencegahan, perkembangan, pengubatan dan membina perubahan tingkah laku dalam kehidupan seseorang (Wan Anor Wan Sulaiman, 2015).

Corey (2003) berpendapat bahawa intervensi dalam bentuk kelompok adalah lebih berkesan jika dibandingkan dengan intervensi yang berbentuk individu. Beliau mengatakan kaunseling kelompok adalah lebih berkesan dari kaunseling individu disebabkan oleh tindak balas yang diterima oleh ahliahli lain dalam kelompok dan lebih bertahan lama terutama dari sudut kesejahteraan dan psikologikal. Kebaikan kaunseling kelompok bukan sahaja boleh digunakan untuk mengurangkan tahap tekanan tetapi juga telah dimanfaatkan oleh pengkaji tempatan dalam merawat permasalahan lain seperti kebimbangan sosial (Wan Abdul Kader 1994), persediaan ke arah persaraan (Ismail 2001), membina kemahiran asertif dan tingkah laku langsang buli (Abdul Malek 2004). Beck (1995), telah menyatakan terapi kognitif secara ringkas bahawa model kognitif mencadangkan bahawa pemikiran yang diputarbelitkan atau tidak berfungsi (yang mempengaruhi mood dan tingkah laku pesakit) adalah perkara biasa kepada semua gangguan psikologikal. Matlamat pendekatan kognitif ialah mengajar seseorang mengenal pasti, menilai dan mengubah pemikiran yang tidak berfungsi dan kepercayaan mereka sendiri (Linda Seligman \& Lourie W. Reichenberg, 2010).

Dalam pendekatan ini, kaunselor memainkan peranan yang sangat penting dan aktif dengan mencabar pemikiran ahli-ahli kelompok yang tidak rasional dan logik. Kaunselor juga memainkan peranan utama dengan mengajar pelbagai kemahiran dan membina kerangka kognitif yang positif yang akan membantu ke arah perubahan tingkah laku. Selain dari itu, ahli-ahli kelompok juga digalakkan supaya berusaha sekuat mungkin mencabar pemikiran yang merosakkan diri sendiri dengan mempraktikan kaedah pendekatan yang dipelajari dalam kehidupan mereka. (Wan Anor Wan Sulaiman, 2014). 
Kaunselor akan membimbing ahli kelompok mengenali saling hubungan alasan, emosi, dan tingkah laku bagi memupuk tanggungjawab ahli kelompok untuk mengakui dan menilai semua sistem kepercayaan yang telah disebatikan dalam dirinya. Kaunselor bukan sahaja mengeluarkan misteri daripada proses terapeutik, tetapi mengajar ahli kelompok mengenai hipotesis kognitif gangguan dan menunjukkan bagaimana kepercayaan yang tidak rasional membawa kepada konsekuen negatif. Celik akal sahaja biasanya tidak membawa kepada perubahan personaliti, tetapi ia menolong ahli kelompok melihat bagaimana mereka terus mengkhianati diri dan apa yang boleh mereka lakukan untuk mengubahnya (Corey, 2009).

Terapi kognitif telah dibangunkan oleh Aaron Beck (2011), beliau menekankan kepentingan sistem kepercayaan dan pemikiran dalam menentukan tingkahlaku dan perasaan. Fokus terapi kognitif ialah memahami kepercayaan yang diputarbelitkan dan menggunakan teknik untuk menukar pemikiran maladaptif sementera menggabungkan secara efektif dan kaedah-kaedah tingkahlaku (Sharf, 2008). Terapi kognitif merupakan suatu jalan kita bercakap tentang hubungan antara bagiamana kita berfikir, bagaimana kita merasa, dan bagaimana kita berkelakuan baik. Terutamanya memberi perhatian kepada idea-idea yang tidak realistik. Terapi kognitif membantu seseorang melihat peranan dalam kehidupannya (Wan Anor Wan Sulaiman, 2014). Kajian Meichenbaum (1977) mendapati teknik pengurusan stres dan penstukturan kognitif berkesan dalam pengurangan stres. Kajian beliau mendapati berlakunya pengurangan anxieti, deprasi, kemarahan setelah subjek menjalani pengurusan stres melalui kaedah kognitif. Kajian beliau juga selari dengan kajian Reynolds \& Coats (1986) yang juga mendapati intervensi kognitif berjaya mengurangkan deprasi, mempunyai kemahiran berdaya tindak dan boleh meningkatkan rasa self-efficacy untuk berhadapan dengan situasi yang boleh menghasilkan stres. Terapi kognitif juga melihat bahawa tekanan yang dialami oleh seseorang ialah berkaitan bagaimana mereka menggunakan kognitif mereka untuk menilai situasi yang mereka alami. Sekiranya seseorang menilai secara negatif maka mereka akan mengalami tekanan begitulah sebaliknya.

Terapis kognitif percaya bahawa kebanyakan faktor yang menyumbang kepada perkembangan ketidakfungsian kognitif, termasuklah biologi manusia dan kecenderungan genetik, pengalaman hidup, pengumpulan ilmu dan pembelajaran. Pengherotan kognitif bermula dalam pembentukan masa kanakkanak dan mencerminkan kepercayaan asas seseorang; menjadikan seseorang mudah terdedah dengan masalah yang meninggalkan kesan ke atas kelemahan kognitifnya (Beck, 1995).

\section{Kesimpulan}

Secara rumusannya, tekanan dalam kalangan polis semakin meningkat dan memberi impak yang besar kepada pegawai polis yang sering melakukan kerja setiap masa. Pihak pengurusan tertinggi Polis DiRaja Malaysia (PDRM) semestinya memandang serius perkara ini dan cuba mencari pelbagai alternatif berbentuk program yang sesuai dan berkesan bagi membantu pegawai polis dapat menggunakan pendekatan tertentu untuk berhadapan dengan situasi tekanan. Antara pendekatan yang agak sesuai boleh digunakan ialah intervensi kaunseling kelompok terapi kognitif yang boleh diberi latihan kepada pegawai polisbagi mengurangkan tahap tekanan dialami secara sederhana dan tinggi.

\section{Rujukan}

Abdul Malek Abdul Rahman. 2004. Kesan kaunseling kelompok tingkah laku kognitif dalam merawat tingkah laku langsang buli di kalangan pelajar sekolah menengah: UPSI

Ambrose, J. A., \& Barua, R. S. 2004. The pathophysiology of cigarette smoking and cardiovascular disease an update. Journal of the American College of Cardiology, 43(10), 1731-1737.

Anderson, G. S., Litzenberger, R., \& Plecas, D. 2002. Physical evidence of police officer stress. Policing: An International Journal of Police Strategies and Management, 25, 399-420.

Anshel M.H. 2000. A conceptual model and implications for coping with stressful events in police work. Criminal Justice Behavior Journal. 27(3):375- 400.

Beck. J. S. 1995. Cognitive Therapy: Basics and Beyond. Guilford Press. 
Beck, A.T., Dozois, D.J.A. 2011. Cognitive therapy: Current status and future directions. Annual Review of Medicine, 62, 397-409

Bakker, A.B. \& Heuven, E. 2006. Emotional dissonance, burnout, and in-role performance among nurses and police officers. International Journal of Stress Management, 13(4), 423-440.

Brown, J., Cooper C.L., \& Kirkcaldy B. 1996. Occupational stress among senior police officers. British Journal of Psychology, 87, 31-45

Cooper, C.1., Sloan, S.J., \& Williams, J. 1988. Occupational Stress Indicator Management Guide. Windsor: SAE Division, NFER, Nelson.

Collins, R. A., \& Gibbs, A. C. C. 2003. Stress in police officers: a study of the origins, prevalence and severity of stress-related symptoms within a county police force. Occupational Medicine, 53: 256-264.

Corey, G. 2003. Theory and Practice of Group Counseling. 6th. Sage Publication.

De la Fuente Solana, E. I., Extremera, R. A., Pecino, C. V., \& Cañadas de la Fuente, G. R. 2013. Prevalence and risk factors of burnout syndrome among spanish police officers. Psicothema, 25(4), 488-493.

Donald I, Taylor P, Johnson S, Cooper C, Cartwright S dan Robertson S. 2005. Work environments, stress and productivity: an examination using asset. International Journal of Stress Management 12(4), 409- 423

Wan Anor Wan Sulaiman. (2014). Effectiveness of cognitive therapy and behavior therapy treatment modules intervention in group counseling among of stress. International Multidisciplinary conference. Asean Economic community: Transformation, policy, partnership and action toward regional prosperity. Jakarta.

Finn, P., \& Tomz, J. E. 1997. Developing A Law Enforcement Stress Program For Officers And Their Families. Washington, DC: U.S. Department of Justice

Gazda, G., Ginter, F., \& Horne, A. 2001. Group counseling and group psychotherapy: Theory and application. Boston: Allyn \& Bacon.

Glading, S. T. 2008. Group : A counseling specialty $5^{\text {th }}$ ed. Upper Saddle River. NJ: Pearson Education.

Hammad, M., Awan, S. H., Akhtar, C., \& Imdadullah, M. (2013). Investigating stress and employee performance in traffic police. International Proceedings of Economics Development \& Research, 55(28), 141-144.

Ismail Alias. 2001. Keberkesanan program persediaan sebelum bersara jabatan perkhidmatan awam Malaysia. Jurnal Pengurusan Awam Jilid 2 Bilangan 1International `Council of Nurses (ICN). 1899-2010.

Kaur, R., Chodagiri, V. K., \& Reddi, N. K. 2013. A psychological study of stress, personality and coping in police personnel. Indian Journal of Psychological Medicine, 35(2), 141147. doi: 10.4103/0253-7176.116240

Liberman, A. M., Best, S. R., Metzler, T. J., Fagan, J. A., Weiss, D. S., \& Marmar, C. R. 2002. Routine occupational stress and psychological distress in police. Policing: An International Journal of Police Strategies and Management, 25, 421-439.

Maslow, H. A. 1968. Toward a Psychology of Being. Van Nostrand

Masilamani, R., Bulgiba, A., Chinna, K., Darus, A., Isahak, M., Kandiben, S., \& Koh, D. 2013. Prevalence and associated factors of stress in the Malaysian police force. ScienceDirect Preventive Medicine, 57, S57-S59.

Mohamed Sazif Mohamed Subri. 2011. The Stress Effect Towards PDRM Personnel: A Case Study on Health Problems and Job Satisfaction in Kedah. Masters Diss., Universiti Utara Malaysia, Sintok, Kedah.

Mohd Awang Idris, Dollard, M., F. \& Winefield, A., H. 2010. Lay theory explanations of occupational stress : the malaysian contex. Cross Culture Management : An International Journal, 17 (2), 135-153.

Myendeki, A. N,. (2008). Job Stress, Burnout and coping strategies of south African Police Officers.

Norvell, N., Belles, D., \& Hills, H. 1998. Perceived stress levels and physical symptoms in supervisory law enforcement personnel. Journal of Police Science \& Administration, Vol. 16, 75-79

Patterson, G. T. 2009. Mental stress and workers' compensation claims among police officers. Journal of Workplace Rights, 14(4), 441-455. 
Raja Maria Diana Raja Ali, (2011) Faktor-faktor yang mendorong tekanan kerja (stres) dikalangan guru-guru sekolah menengah di daerah Pasir Puteh. Masters thesis, Open University Malaysia.

Rudestam, K.E. 1982. Experiential groups in theory and practice. Monterey, CA: Brooks/Cole

Salmah Binti Othman. (2009). Kecerdasan emosi dan tekanan kerja serta hubungannya dengan komitmen kerja dalam kalangan anggota polis diraja Malaysia. Tesis Sarjana UUM.

Selye H. 1976. Stress in health and disease Butterworth's, Inc. Boston, MA

Sinar Harian, 12 Disember 2009. Anggota polis bunuh diri. Sinar Karangkraf Sdn. Bhd., Selangor, Malaysia.

Stinchcomb, J. B. 2004. Searching for stress in all the wrong places: combating chronic organizational stressors in policing. Police Practice and Research, 5, 259-277.

Van Hasselt, V.B., Sheehan, D.C., Malcolm, A.S., Sellers, A.H., Baker, M.T., \& Couwels, J. 2008. The law enforcement oycer stress survey (leoss), evaluation of psychometric properties. Behavior Modification 32(1), 133-151.

Violanti, J.M., Vena, J.E., \& Petralia, S., 1998. Mortality of a police cohort: 1950-1990. American Journal of Industrial Medicine, 33(4), 366-373.

Wan Abdul Kader Wan Ahmad. 1994. Kaunseling Kelompok. Pengurangan kebimbangan Sosial. Kuala Lumpur. Dewan Bahasa dan Pustaka.

Wu H, Chi TS, Chen L, Wang L, Jin YP. 2010 Occupational stress among hospital nurses: crosssectional survey. Journal Adv Nurs, 66(3):627-34.

Wan Sulaiman, W.A. (2016). Keberkesanan modul intervensi terapi kognitif dan terapi tingkah laku dalam kaunseling kelompok menangani tekanan terhadap jururawat. Thesis PhD tidak dipublikasikan. Bangi: Universiti Kebangsaan Malaysia

Wan Sulaiman, W.A, Mohd Dahlan HA Malek, Wan Nor Fatini, Adi Fahrudin. (2017). Effectiveness of group counseling using cognitive and behavior therapy intervention to reduce stress among nurses. Universal Journal of Psychology 5(5): 231-237, DOI: 10.13189/ujp.2017.050504http://www.hrpub.org/download/20171230/UJP4-19409657.pdf 